Dialectologia. Special issue, $\mathbf{V}(2015), 29-51$.

ISSN: 2013-2247

Received 28 May 2015.

Accepted 15 September 2015.

\title{
ON THE DE + INFINITIVE CONSTRUCTION (DEÍSMO) IN SPANISH
}

\author{
Carlota de BENITO ${ }^{1}$ \& Enrique PATO ${ }^{2}$ \\ Universität Zürich $^{1} /$ Université de Montréal $^{2}$ \\ carlota.debenitomoreno@uzh.ch / enrique.pato-maldonado@umontreal.ca
}

\begin{abstract}
This paper aims at providing the first complete description of the de + infinitive construction in Peninsular Spanish. Previous works have either mentioned briefly its existence by locating it in some Southern dialects (Andalusia or Extremadura) or analysed the syntactic behaviour of the construction in small areas, and have seldom used data from exhaustive corpora. Using the currently available data from the Corpus Oral y Sonoro del Español Rural (COSER), we provide a precise geographical distribution of the phenomenon and a detailed description of the construction.
\end{abstract}

\section{Keywords}

Spanish, grammar, de + infinitive construction, deísmo

\section{SOBRE LA CONSTRUCCIÓN DE + INFINITIVO (DEÍSMO) EN ESPAÑOL}

\section{Resumen}

En este artículo pretendemos proporcionar la primera descripción completa de la construcción de $d e+$ infinitivo en español peninsular. Los trabajos anteriores o bien han mencionado someramente su existencia, localizándola en algunas variedades del sur (Andalucía o Extremadura), o bien han analizado el comportamiento sintáctico de la construcción en regiones concretas, basándose rara vez en datos obtenidos exhaustivamente a partir de corpus. Gracias a los datos del Corpus Oral y Sonoro del Español Rural (COSER) disponibles actualmente, podemos ofrecer la distribución geográfica precisa del fenómeno y una descripción detallada de la construcción.

\section{Palabras clave}

español, sintaxis, construcción de + infinitivo, deísmo 


\section{Introduction}

Some modern Spanish varieties show a wide number of infinitive clauses preceded by the preposition de where the Standard language requires a different preposition or no preposition at all, for example oí de cantar ('I heard [prep.de] singing'), vi de llover ('I saw [de] raining'), lo he visto de caer ('I have seen him/it [de] fall') or comencé de/a limpiar ('I started [de/a] to clean'). This work will study the first three cases, which are examples of the so-called deismo. The last example, on the other hand, illustrates a change of the preposition (where de replaces $a$ ), a phenomenon that will not be studied here. ${ }^{1}$

Gómez Torrego (1999: 2128) has described deísmo as the "superfluous use of the preposition de in infinitive subordinate clauses" (our translation). This 'superfluous' use is very frequent in Andalusia and Extremadura (cf. Zamora Vicente 1970: 330; Llorente 1980: 36; Gómez Torrego 1999: 2128) and it has been traditionally considered incorrect from a prescriptive point of view (cf., for example, Di Tullio 2011: 185). The cases of deismo differ from other examples of $d e+$ infinitive in that the preposition is not required by the verb, that is to say, it only appears before infinitive clauses, and not before finite subordinate clauses or nominal phrases (cf. 1). ${ }^{2}$
a. La vi (de) llorar
('I saw her [de] crying').
b. La vi (*de) que lloraba
('I saw $\left[{ }^{*} d e\right]$ that she was crying').
c. La vi $(*$ de) vestida de blanco
('I saw her [*de] dressed in white').
d. Vi $(*$ de) las lágrimas
('I saw [ $\left.{ }^{*} d e\right]$ the tears').

In some other cases, however, the presence or absence of the preposition de has

\footnotetext{
${ }^{1}$ Di Tullio $(2011,2012)$ includes in her studies the cases we call here deismo together with the cases of alternation between de and another preposition and some cases in which de is not optional, such as dijo de quedar. We do not include this last type, since the preposition is required and there is no equivalent sentence without de ( ${ }^{*}$ dijo quedar). In fact, in this case decir seems to take a slightly different meaning of the original 'to say', meaning 'to propose' instead. Considering these cases separately also avoids some problems found in Di Tullio's analysis, such as proposing that the appearance of de prevents the 'posteriority' reading (implying that examples such as no me pesa de haberme quedado are impossible, but see example [4a]) or that the infinitive preceded by de allows for a non-controlled reference, which does not seem to be the case in our corpus.

${ }^{2}$ The presence of the preposition de before finite clauses, the so-called dequeísmo, does not seem to occur in the same contexts as deísmo, cf. §3.2, but more research is needed on this topic.
} 
Dialectologia. Special issue, $\mathbf{V}(2015), 29-51$.

ISSN: 2013-2247

been considered to produce syntactic effects. For instance, in sentences with the light verb dar ('to give'), the bare infinitive is considered the subject of the main clause (as in 2a), while the prepositional infinitive would work as a noun modifier of the direct object (as in 2b) (NGLE 2009: 2543). That is to say, the presence of the preposition would trigger a change in the syntactic function of the infinitive. In other cases, it seems that the preposition is sometimes present with nominal phrases too (cf. $2 \mathrm{c}$ and 2d). According to NGLE, the presence of de impersonalizes the main clause, since it prevents the infinitive clause from appearing in the subject position.
a. Da pena verlo
('I feel sorry (to) see it/him').
b. Da pena de verlo
('I feel sorry to see it/him').
c. Me da pena María
('I pity Mary').
d. Me da pena de María
('I pity [de] Mary').

This work has several goals. First, it aims to document the phenomenon in Peninsular Spanish and to present its geographical extension for the first time, thanks to the Corpus Oral y Sonoro del Español Rural (COSER) data (§2). Second, it will try to offer a description of the phenomenon, by considering it as an example of microvariation in Peninsular Spanish syntax (§3). In order to do so, we will focus on the type of verb (§3.1) and the different semantic values of the preposition de (§3.2). We will also briefly present its medieval antecedents (§3.3), as suggested by NGLE (2009: 3257), and Pato \& De Benito (2012). In section $\S 4$, we will shortly examine some parallel Romance constructions. In the next section (§5), we will review the hypothesis proposed so far about deísmo constructions and outline some further research lines that we would like to pursue in the future. Last, we will summarize our findings in the conclusion (§6).

\section{Geolinguistic Distribution}

Very few studies have offered examples of the 'de + infinitive' construction (cf. Llorente 1980: 36; Gómez Torrego 1999: 2129). As regards the data in the different 
available atlases, the Atlas Lingüístico de la Península Ibérica (ALPI) unfortunately does not shed light onto the phenomena, and provides no data for Andalusia or Extremadura. Out of four questions that have an infinitive in a context where the preposition may appear (\#259. No saben freír un huevo 'They don't know how to fry an egg', \#280. A ninguna le agrada ponerse la ropa de otra 'None of them likes to wear clothes from someone else', \#309. Se va a pudrir la fruta 'The fruit is going to rot' $y$ \#343. ¿Os queréis callar? 'Would you shut up?'), only the second (\#280) shows an example of the infinitive proceeded by the preposition de (a ninguna le agrada de ponerse la ropa de otra) in one single locality (Córdoba 502. Fuenteovejuna, current Fuente Obejuna), in a 52 year-old labourer who corrects himself right afterwards. Although the verbs selecting the infinitive in these four questions (saber, agradar, querer, and ir) are not the ones that most favour the preposition de, the absence of examples shows that the questions of the ALPI where sometimes too structured, especially in regards to syntax. Examples of prepositional infinitives are frequent in colloquial speech, and can be found in literary works previous to the ALPI:

(3) a. estaba yo tan tranquila sentá en mi escalón cuando vi de venir a Joseíto... (Arturo Reyes, La bravía, 1888). ('I was peacefully sitting on my step when I saw Joselito [de] come').

b. Lejos muy lejos de España/ Yo oí de cantar a un ruiseñor... (Antonio Macías, Jabegote, Popular song). ('Far far away from Spain/ I heard a nightingale [de] sing').

The Atlas Lingüístico y Etnográfico de Andalucía (ALEA) includes only one map with the conditions to provide some information on the phenomenon under study (\#1869. No me pude mover 'I could not move'). However, the data from the ALEA, like those from the ALPI, do not offer any examples of the preposition de before the infinitive, which proves that linguistic atlases present some limitations to the study of syntactic phenomena (cf. Fernández-Ordóñez 2007).

Lastly, the Atlas lingüístico (y etnográfico) de Castilla-La Mancha (ALECMAN) includes the same question (SIN-59. No me pude ni mover), also with no relevant information, but adds another one ( $\mathrm{SIN}-77$. Suele haber) where the vernacular form is found (suele de haber) in a single locality in the South of Ciudad Real (CR510. 
Dialectologia. Special issue, $\mathbf{V}$ (2015), 29-51.

ISSN: 2013-2247

Mestanza). The Atlas has four more maps that are crucial for the study of the phenomena in this area (SIN-88: Dejar (de) salir, SIN-89: Hacer (de) reír, SIN-90: Hacerse (de) rogar y SIN-91: Deber (de) hacer). They show that both forms, with and without the preposition, appear in all the provinces of Castilla-La Mancha without a clear geographical pattern.

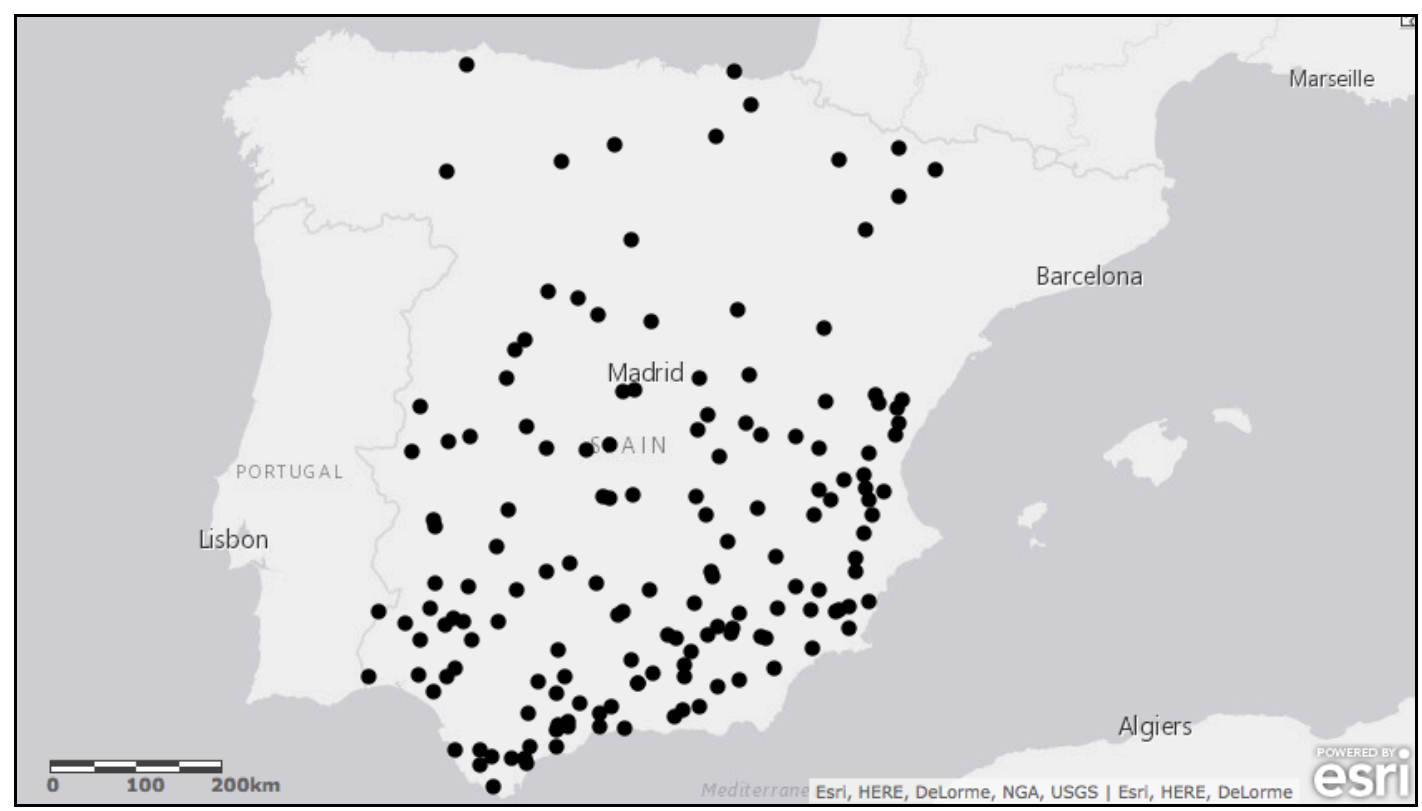

Map 1. Distribution of deísmo in Peninsular Spanish (COSER data)

The data from the Corpus Oral y Sonoro del Español Rural (COSER) offer precious information for the study of dialectal syntax, since the corpus consists of semidirected interviews to rural elderly speakers. We found examples of deísmo in Andalusia (Almería, Granada, Huelva, Cádiz, Málaga, Sevilla, Córdoba and Jaén), Murcia, Extremadura (Cáceres and Badajoz), Castilla-La Mancha (Albacete, Ciudad Real, Guadalajara, Toledo and Cuenca), the Valencian Community (Alicante, Valencia and Castellón) and Madrid. ${ }^{3}$ Although the frequency of deísmo in the South (and East) of

\footnotetext{
${ }^{3}$ The alphabetical list of localities is the following: Abarán (Murcia), Ahín (Castellón), Alcalá de los Gazules (Cádiz), Alcolea (Almería), Alcolea del Pinar (Guadalajara), Aldea de la Mesa (Jaén), Algar de Palencia (Cádiz), Almadén de la Plata (Sevilla), Almajalejo (Almería), Álora (Málaga), Alozaina (Málaga), Altarejos (Cuenca), Antequera (Málaga), Argelita (Castellón), Arjona (Jaén), Arroyo de San Serván (Badajoz), Bacares (Almería), Barrax (Albacete), Bélmez (Jaén), Belmonte (Cuenca), Benijófar (Alicante), Benimodo (Valencia), Bonares (Huelva), Brozas (Cáceres), Cabra del Santo Cristo (Jaén), Cádiar (Granada), Calasparra (Murcia), Caleruela (Toledo), Campocámara (Granada), Camporrobles (Valencia), Cañada del Gamo (Córdoba), Cañaveral de León (Huelva), Cardenete (Cuenca), Cardeña (Córdoba),
} 
Spain (Andalusia, Murcia, Extremadura and Castilla-La Mancha) is indisputably higher, we have also found some examples of deísmo in the Northern half (Asturias, Ávila, Burgos, Guipúzcoa, Huesca, León, Palencia, Salamanca, Segovia, Teruel, Valladolid, Vizcaya and Zaragoza). ${ }^{4}$ Thanks to COSER data, we can present a first geographical distribution of the deísmo and specify the areas where is registered (cf. NGLE 2009: 3257), see Map 1. Interestingly enough, the map already seems to suggest that deísmo is not as frequent in Extremadura or Castilla-La Mancha as it is in Andalusia, Murcia or the Valencian Community, according to the number of localities that presented examples of deísmo.

\section{Verbal infinitives}

Using the examples from the COSER, we will describe the use of the infinitive

Casarabonela (Málaga), Casares (Málaga), Casariche (Sevilla), Casas de Juan Gil (Albacete), Casas de Soto (Valencia), Casas del Río (Ciudad Real), Castillblanco de los Arroyos (Sevilla), Constantina (Sevilla), Deifontes (Granada), El Álamo (Madrid), El Álamo (Madrid), El Mojón (Alicante), El Rocío (Huelva), Enguera (Valencia), Escúllar (Almería), Estación de Salinas (Málaga), Facinas (Cádiz), Fátima (Granada), Fonelas (Granada), Fontanars dels Alforins (Valencia), Fuente del Pino (Murcia), Fuenterrobles (Valencia), Fuente Vaqueros (Granada), Galera (Granada), Gil Márquez (Huelva), Horcajo de Santiago (Cuenca), Huéscar (Granada), Higueruela (Albacete), Humanes (Madrid), Jimena de la Frontera (Cádiz), Jubrique (Cádiz), La Garrovilla (Badajoz), La Higuera de Arjona (Jaén), La Nava de Ricomalillo (Toledo), La Romaneta (Alicante), Liétor (Albacete), Llerena (Badajoz), Lo Ferro (Murcia), Los Palacios Blancos (Murcia), Los Pascuales (Jaén), Lucena del Cid (Castellón), Macastre (Valencia), Malagón (Ciudad Real), Manilva (Málaga), María (Almería), Mas de los Mudos (Valencia), Millares (Valencia), Mogón (Jaén), Moraleja (Cáceres), Morata (Murcia), Navahermosa (Toledo), Ojén (Málaga), Orellana de la Sierra (Badajoz), Osuna (Sevilla), Paterna de Rivera (Cádiz), Paulenca de Guadix (Granada), Pedralba (Valencia), Peñolite (Jaén), Pilas (Sevilla), Pizarra (Málaga), Pliego (Murcia), Porzuna (Ciudad Real), Povedilla (Albacete), Puebla de Arenoso (Castellón), Puebla de don Fadrique (Granada), Puerto Real (Cádiz), Pulgar (Toledo), Quesa (Valencia), Rincón de Seca (Murcia), Riogordo (Málaga), Rosal de la Frontera (Huelva), Ruiduera (Ciudad Real), Salinas (Alicante), San José de Malcocinado (Cádiz), Sanlúcar la Mayor (Cádiz), Santa Ana (Jaén), Santaella (Córdoba), Santa Olalla de Cala (Huelva), Santiuste de San Juan Bautista (Segovia), Sierra de Yeguas (Sevilla), Sieteiglesias (Madrid), Singla (Murcia), Talaván (Cáceres), Tomelloso (Ciudad Real), Torre Alháquime (Cádiz), Torrecampo (Córdoba), Torrejón el Rubio (Cáceres), Torrox (Málaga), Torvizcón (Granada), Totalán (Málaga), Uclés (Cuenca), Valencia del Ventoso (Badajoz), Valeria (Cuenca), Vélez-Blanco (Almería), Villablanca (Huelva), Villaconejos de Trebeque (Cuenca), Villanueva de las Torres (Granada), Villanueva del Duque (Córdoba), Yebra (Guadalajara), Zafarraya (Granada), Zalamea (Badajoz), Zalamea la Real (Huelva), Zufre (Huelva), Zulema (Albacete).

${ }^{4}$ In Alaraz (Salamanca), Anaya (Segovia), Banastón (Huesca), Bandaliés (Huesca), El Barco de Ávila (Ávila), Fuentes Claras (Teruel), Gabiria (Guipúzcoa), Grullo (Asturias), Horcajo Medianero (Salamanca), Humada (Burgos), La Horra (Burgos), Lequeitio (Vizcaya), Lucillo (León), Oliván (Huesca), Pedruzo (Burgos), Rubielos de Mora (Teruel), San Mateo de Gállego (Zaragoza), Santervás de la Vega (Palencia), Urriés (Zaragoza) and Velascálvaro (Valladolid). Our search in the Northern provinces did not include the fieldnotes, but only the COSER interviews currently available in the COSER web. 
Dialectologia. Special issue, $\mathbf{V}$ (2015), 29-51.

ISSN: 2013-2247

with preposition, focusing on the type of verb and the meaning of the preposition.

\subsection{The Type of Verb}

According to Di Tullio (2011: 181), verbs that favor the presence of de in Spanish are mainly verbs of volition and intention (espero de verte pronto; pienso de hacer algunas cosas), verbs of attempt (probé de sacar el tornillo), verbs of acceptance (aceptó de venir a cenar), verbs of influence (me pidió de ir a jugar) and verbs of occurrence (me ocurrió de estar en la cama). The presence of de has been also attested with verbs of belief (cree de ser la más lista) and verbs of communication (dijo de haber venido). Her data suggest, however, that the geographical factor is of some relevance, since she does not find examples of verbs of perception in America (cf. also Camus 2013), who finds differences between the verbs that accept deísmo in Andalusia and Extremadura compared with Castilla-La Mancha).

The COSER data largely confirm (although not for verbs of communication) ${ }^{5} \mathrm{Di}$ Tullio's previous description and expand it, by attesting verbs of perception. The attested verbs include: dejar/permitir de, ver de, hacer de, hacer falta de, era costumbre/probable de, gustar de, dar miedo/pena/reparo de, costar de, poder de, querer de, desear de, pensar de, interesar de, tocar de, sentir de, conocer de, ofrecer de, procurar de, intentar de, soler de. In order to shed some light into the raw data, we propose a classification into six semantic groups, namely, verbs of affection, semantically impersonal constructions, verbs of perception, verbs of volition and intention, and verbs of manipulation, which we briefly describe in what follows:

\footnotetext{
${ }^{5}$ The lack of documentation of verbs of communication has two explanations. First, the COSER does not favor the occurrence of such contexts and second, the majority of verbs of communication collected by Di Tullio are examples in which the preposition is required by the verb (habló de venir) or seems to be lexicalised (decir de venir), which have not been considered in this study.

The only cases of infinitive preceded by preposition in Portuguese (besides those required by the verb) are with main verbs of speech (such as dizer, insistir, pedir, rogar, solicitar) and with the preposition para. Interestingly enough, the usage of dizer para in Portuguese seems to be very similar to the use of decir de in Spanish: Os pais disseram aos miúdos [para vir(em) para casa cedo] Los padres les dijeron a los niños de venir pronto a casa ('los padres' are subjects of dizer).
} 
1) Verbs of affection: The infinitive clause occupies the subject position and the external argument (an experiencer) is encoded by a dative pronoun or noun phrase. These verbs not only showed deísmo in Old Spanish, but also regularly encoded the theme by a de phrase, regardless of its syntactic status (be it an infinitive clause or a noun phrase), hence appearing in syntactically impersonal constructions (cf. Elvira, 2011). The subject of the infinitive is controlled by the dative argument of the main clause.

(4) a. vamos, me podía haber ido a la fábrica, o como se iba alguna gente a Alemania, pero me gustaba el campo. Y no me pesa de haberme quedao en el campo (COSER-2103, Bonares, Huelva). ('Come on, I could have gone to the factory, or as some people did go to Germany, but I liked the country. And I do not regret [de] having stayed in the countryside').

b. No había salío de mi casa nunca. Me costó de adaptarme yo allí (COSER-214, Liétor, Albacete). ('I had never left my house. I struggled to adapt myself there').

2) Semantically impersonal constructions: The infinitive clause also occupies the subject position and the subject of the indefinite is interpreted as generic or indefinite. ${ }^{6}$ We find both single verbs (convenir, tocar, pertenecer) and complex verbal phrases containing a light verb and a bare noun (ser costumbre, dar pena, dar miedo, hacer falta, tener costumbre). The impersonal reading may be cancelled by adding a dative experiencer (that will control the subject of the infinitive), hence obtaining an affection reading (convenir, pertenecer).

(5) a. Aquí la víspera de las vendimias se tenía por costumbre de hacer bailes (COSER-1636, Valeria, Cuenca). ('Here the harvest eve we had the habit of making balls').

b. Eso tiene que dar mucha pena, de irte a la residencia y dejar to lo que tienes aquí (COSER-1607, Cardenete, Cuenca). ('That has to produce a lot of grief, [de] going to the retirement home and leaving all you have here').

\footnotetext{
${ }^{6}$ Example (b) has a reflexive infinitive, which necessarily shows person and number agreement. The choice of the $2^{\text {nd }}$ person singular is actually determined by the fact that the subject has an indefinite reading, since this is one of the verbal persons that allow for such a reading in Spanish.
} 
Dialectologia. Special issue, $\boldsymbol{V}$ (2015), 29-51.

ISSN: 2013-2247

3) Verbs of perception: The infinitive clause appears in the object position. The subject of the infinitive is controlled by the accusative argument of the main clause. ${ }^{7}$ There seems to be a restriction that requires that the subject of the perception verb be an experiencer, since we have not found examples with agentive perception verbs such as mirar ('to look') or escuchar ('to listen'), as opposed to ver ('to see') and oír ('hear').

(6) a. Jamás ha ido, a la cerca aunque me ha visto de ir p'abajo, nunca, nunca, nunca... no ha ido nunca (COSER-723, Orellana de la Sierra, Badajoz). ('He never went to the fence, but he has seen me [de] going down, never, never, never... He did not ever go').

b. Hubo una época que yo a mi tío le oía de decir que se llamaba don X (COSER-723, Orellana de la Sierra, Badajoz). ('There was a time when I used to hear my uncle [de] saying that he was called $\mathrm{Mr} \mathrm{X}^{\prime}$ ).

4) Verbs of manipulation: The infinitive also appears in the object position and its subject is also controlled by the accusative argument of the main clause. The subject of the main verb, as opposed to the previous group, is always an agent.

(7) a. Sabíamos coger... mover el vino y olerlo, eso fue lo que me dejó, de bebérmelo no me dejó (COSER-2103, Bonares, Huelva). ('We knew how to grab..., move the wine and smell it, that's what $s /$ he allowed me to do, $s /$ he did not allowed me to drink it').

b. Me ha[n] hecho mis padres de correr (COSER-4235, Navahermosa, Toledo). ('My parents made me run').

5) Verbs of volition and intention: The infinitive also appears in the object position. The subject of the main verb is an agent and it controls the subject of the infinitive.

(8) a. Y mis hijas como se han criao con ella, pos están deseandito de venir (COSER-2114, Gil Márquez, Huelva). ('And my daughters, since they have grown up with her, well, they

\footnotetext{
${ }^{7}$ The syntactic complexity of these clauses, that apparently take two objects, is discussed in Hernanz (1999).
} 
are willing to come').

b. me dijo: Luisa, hija, procura de ir aunque sean poquitos días, pero procura de ir al viaje de novios (COSER-728, Valencia del Ventoso, Badajoz). ('She said to me: Luisa, my daughter, try to go even if it is just a few days, but try to go on the honeymoon trip').

6) Other verbal groups: Although this situation is less common, de also appears before some infinitives in verbal groups with modal verbs such as poder, querer, and soler, which behave as verbal periphrasis.

(9) a. Mientras tenía para poderle de dar, se lo daba (COSER-2114, Gil Márquez, Huelva). ('While I had enough to be able to give to him, I gave it to him').

b. Suele de pasar (COSER-3102, Abarán, Murcia). ('It tends to happen').

\subsection{The preposition de}

There are several aspects that need to be discussed with respect to the preposition de. In the first place, its syntactic status is not clear, and several hypotheses have been offered in the literature (Huot 1981). Second, the fact that only the preposition de is used in this structure also deserves some attention. Last, it should be asked if the presence or absence of this preposition has any consequences in the meaning of the clause. We will also consider the fact that de is precisely the preposition that appears in dequeísmo.

\subsubsection{Syntactic status of de}

The question whether de should be considered an actual preposition or something else in these constructions has been largely debated in the literature. As shown above, the preposition is not selected by the main verb, since it only appears with infinitive clauses, ${ }^{8}$ but never (or very seldom, cf. below) with nominal or finite

\footnotetext{
${ }^{8}$ The list of infinitives that appear in the de + infinitive construction is abundant. The recorded cases show that the verbs with a greater number of occurrences are verbs of movement and verbs of
} 
Dialectologia. Special issue, $\boldsymbol{V}$ (2015), 29-51.

ISSN: 2013-2247

clausal objects. This suggests that de has stopped working as a real preposition in these cases, turning instead into a complementizer specialized in introducing nonfinite clauses. This is exactly what Huot (1981) proposes for the similar constructions in French and what Skytte, Salvi \& Manzini (2001) suggest for Italian. For Spanish, Di Tullio (2011, 2012) and Camus (2013) defend a similar interpretation.

On the other hand, the NGLE (2009) and Díaz Montesinos (2012) consider that de keeps its prepositional status. This approach has syntactic implications: since Spanish is said not to accept prepositional subjects, the infinitive clause preceded by de is also assumed not to be the subject, implying that the sentences in types 1) and 2) are syntactically impersonal. According to this interpretation, when the preposition does not change the syntactic structure of the clause, it will be merely considered an expletive.

In section §5, we will explore another possibility that includes these two approaches. We believe that structures with deismo are part of a larger tendency found in Spanish, actually in most Romance languages, to develop preinfinitival particles, such as English to (to say, to sing) or Romanian a (a spune, a cânta).

\subsubsection{Why de?}

As previously stated, prepositional infinitives are a Late Latin/Romance innovation (Beardsley 1921; Schulte 2007). According to Schulte (2007), in most cases the preposition adds its own meaning to the construction, producing different types of subordinate clauses (final, temporal, etc.). However, there is not a straightforward explanation as to why the preposition de is the one that appears in deísmo.

As it is known, the meanings of the preposition de are varied and diverse. Among them are: 1) origin/source (es de Madrid), 2) attribute (hombre de carácter), 3) indeterminate amount (le dieron de puñaladas), 4) partitive (varios de los presentes), 5) cause (está muerto de miedo), 6) manner (entró de espaldas), 7) emphasis (el tonto de Juan), 8) condition (de ir al cine, sería el jueves).

perception, such as salir, pasar, ir, vivir, llegar, ver, terminar, correr, tirar, trillar, bailar, trabajar, sacar, andar, gastar, moler, callar. And some others like hacer, coger, tener, cantar, hablar. 
It is possible that more than one of these meanings is related to the cases of deísmo. However, it seems likely that as Elvira (2009b, 2011) notes, the semantic value of 'origin' can be traced at least in affection verbs, since it appeared in Old Spanish with these verbs, and not only with infinitival clauses, but also with nominal phrases (reflecting a Latin Dative/Genitive pattern). In Modern Standard Spanish, however, de no longer appears (at least not regularly) before nominal phrases with these verbs, although examples with types 1 and 2 are not rare (10).

(10) a. Me da miedo de volverme loca (Juan Valera, Pepita Jiménez, 1864). ('I'm afraid of going crazy')

a'. Me da miedo (d)el perro ('I am afraid of the dog').

b. ¡Hace años que bajaste la persiana y no te importa de nadie! (Alberto Daneri, Matar las preguntas, 1981; cf. Díaz Montesinos, 2012). ('It's been years since you closed the shutters and you don't care about anybody!').

On the other hand, the use of de is also explained because, due to its many different meanings, it may also work as a default preposition (it actually appears in many verbal periphrases: debe de ser, ha de ir, es de notar). This is further supported by the fact that $d e$, as opposed to the other most frequent preposition $a{ }^{9}$ is also the preposition that precedes finite clauses in the dequeísmo construction. As Schulte (2007) notes, adjunct infinitive clauses in Spanish, always headed by a preposition, are usually in competition with finite clauses whose complementizers are cognates of the prepositions in the infinitive clauses. Although there does not seem to be a one to one correspondence between dequeísmo and deísmo sentences, it seems only logical that the same preposition is used to introduce argumental clauses, be they finite or not.

\subsubsection{Does de add a difference of meaning?}

The discussion of the status and the meaning of the preposition is related to the question whether the presence of de triggers a change of meaning. Authors defending

\footnotetext{
${ }^{9}$ Schulte (2007) shows that infinitive constructions with $a$ are the most frequent.
} 
Dialectologia. Special issue, $\mathbf{V}$ (2015), 29-51.

ISSN: 2013-2247

that de is a complementizer agree that there are no differences of meaning in the alternations found in (11) (Di Tullio 2011, 2012; Camus 2013). On the other hand, Díaz Montesinos (2012), who only addresses the cases where deísmo appears in subject clauses, considers de to be a preposition that triggers the syntactic impersonalization of the main clause and proposes that a difference of meaning is to be found in the alternation (cf. 11). According to this author, these examples belong to different constructions: (11c) is an example of the stative construction while $\left(11 c^{\prime}\right)$ is an example of the impersonal construction.
a. Nos mando salir/ Nos mando de salir.
('He sent us out').
b. No pudimos ir/ No pudimos de ir.
('We could not go').
c. Les gusta trabajar.
('They like to work').
$c^{\prime}$. Les gusta de trabajar.
('They like to work').

Once again, we would like to propose an intermediate possibility, according to which de would have originally conveyed some kind of source meaning - most likely related to Díaz Montesinos' (2012) proposal -, but that, later on, the rapid increase in the use of de was possible because its very broad meaning favored its weakening and it eventually became a barely significant introductory particle to the infinitive rather than a real contributor to the meaning of the sentence. The meaning of de that would have permitted such a weakening was most likely relative de (i.e., 'relative to, concerning, about, in the matter of'), which could be used naturally with a large number of verbs (pensar de, asmar de, auenturarse de, dubdar de, etc.).

However, since there seems to be intra-speaker variation on the presence or absence of $d e$, we believe that de + infinitive clauses may be sensitive to certain semantic parameters. In future research, we would like to examine this possibility taking into consideration two different facts: 1) the preposition only appears with some $\mathrm{V} 1$, so it would be possible to talk about a constructional meaning explained by certain features common to all these V1; and 2) the preposition only appears in some (but not all) cases of the same V1, therefore, we should look for the reason for this difference in the discourse. These two possibilities are not exclusive, but they likely 
show different aspects of the evolution of the phenomenon.

\subsubsection{Deísmo and dequeísmo}

Whether or not deísmo and dequeísmo (the use of de before finite clauses headed by the complementizer de, as in pienso de que es simpática 'I think (de) that she is nice') are related phenomena is a recurrent matter in the literature on deismo. Díaz Montesinos (2012), for example, considers them not only to be related, but as the same variation process - although he does not develop the question further. On the other hand, Camus (2013) categorically rejects the connection between both phenomena. He states that the Ciudad Real speakers that accept deísmo do not accept dequeísmo examples (even more, they seem to show a tendency to the opposite phenomena, queísmo). This, he says, will support Demonte's (2003) theory on two types of Romance languages.

However, the situation is not that simple. Many of the speakers that show deísmo in the COSER interviews also show dequeísmo, and it seems premature to state that one excludes the other. ${ }^{10}$

Camus also bases his hypothesis of differentiating deismo from dequeísmo on the fact that, in the latter, de has been said to have some evidential meaning (Demonte \& Fernández Soriano, 2001, 2005), while in the former de seems to be meaningless. It must be said, however, that not all authors agree on the evidential meaning of de in dequeísmo examples, as there is not a consensus on de's lack of meaning in deísmo examples.

According to Demonte (2003), de would index the relationship between the speaker and what is stated in the subordinate clause, but not to indicate that something is been affirmed, but to refer that the speaker believes that what is being declared is true. On the other hand, authors like Almeida (2009) have shown that there

\footnotetext{
10 Actually, this coexistence of constructions is found even in Ciudad Real (Malagón, COSER-1414), where we found examples of deísmo (i) and dequeísmo (ii) in the same speaker:

(i) Si no me dejaban de jugar digo: "juego", o "jugo", o como se decía eso. ('If they wouldn't let me (de) play, I say: "I play or I plays" or whatever it was said'.)

(ii) Porque entonces se estipulaba de que había que pagar al ayuntamiento [...] ('Because it was then stipulated (de) that one should pay to the City Hall'.)
} 
Dialectologia. Special issue, $\boldsymbol{V}$ (2015), 29-51.

ISSN: 2013-2247

seems to be an important influence of priming effects in both dequeísmo and queísmo structures, suggesting that the absences or presence of the preposition is not so much determined by differences of meaning but on the surrounding context.

\subsection{Historical predecessors}

In Latin, infinitive subordinate clauses are composed of verbs dicendi, verbs of understanding/cognition and meaning, verbs of volition, verbs of emotion and 'servile' verbs (such as possum, debeo and soleo). However, infinitive verbs were never preceded by prepositions in Latin (cf. Schulte 2007; Meyer-Lubke [Gram. III §386]; Beardsley 1921: 106-107).

From a historical point of view, we can find some alternating verbs (cf. NGLE 2009: 3256-3257). That is the case of conviene de (hazer):

(12) a. las cosas enque conuiene fazer Atacir (Alfonso X, Judizios de las estrellas). ('The things that must be done Atacir').

b. las cosas quel conuiene de fazer (Alfonso X, Judizios de las estrellas). ('The things that must be done').

Dejar de, creer de also admitted (although did not require) the preposition:

(13) a. Al tiempo que estuvieron en clausura no dejaban de salir algunas á lo que era menester, pero siempre acompañadas (Jerónimo de Mendieta, Historia eclesiástica indiana, 1564). ('When they were enclosed they did not stop going out for whatever they needed, but always accompanied').

b. creyendo de engañar al dicho Francisco de las Casas (Hernan Cortés, Cartas de relación, 1516). ('believeing [de] deceive the said Francisco de las Casas').

Other verbs like aconsejar, proponer, acordar, prometer, acostumbrar, procurar o determinar: 
(14) a. preguntole si se hauia aconsejado de fazer la batalla (Gran Conquista de Ultramar). ('He asked him if it had been advised to engange in battle').

b. E estos dos reys propusieron de venir en sus reynos \& entrar enellos con poderio (Guido de Columna, Historia troyana). ('And these two kings proposed [de] coming to their kingdoms and enter them powerfully').

c. acordaron de fazer vna carta pora aquel que era cabdiello dela hueste delos almorauides (Alfonso X, Estoria de España II). ('They agreed to do a letter for that who was commander of the Almoravid host').

d. en aquella priuança grand que tenie prometio de dar le el principado de los sacerdotes (Alfonso X, General estoria IV). ('In that great favout the principality of the priests had promised to give him').

e. Aquesto acostumbran de fazer algunos hombres non mucho sabios que fablan con los labradores (Paladio, Tratado de Agricultura). ('This is what some not very wise men that speak with the farmers tend to do').

f. procuró de saber por sus espías en la tierra de los moros qué çibdades o villas estuviesen con menos recaudo (Sebastián de Horozco, El Libro de los proverbios glosados, 1544). ('He tried to know through his spies in the land of the Moors what cities or towns were less protected').

g. Pizarro determinó de salir de Lima para visitar las ciudades de Trujillo y San Miguel (Pedro Cieza de León, Crónica del Perú, 1551). ('Pizarro determined to leave Lima to visit the cities of Trujillo and San Miguel').

And even auxiliary verbs, such as poder (15a) and soler (15b): ${ }^{11}$

(15) a. bien ternia causa si pudiesse de maldezir tu noble juuentud (Oliveros de Castilla). ('It would be right, if your noble youth could [de] curse').

b. por donde mas el rey don alfonso solia de andar (Gauberto Fabricio de Vagad, Crónica de Aragón). ('Where more often the King Alfonso used to walk').

\footnotetext{
${ }^{11}$ For deber + inf. and deber de + inf. from a historical point of view cf. Martínez Díaz \& Vila Pujol (2012).
} 
Dialectologia. Special issue, $\boldsymbol{V}$ (2015), 29-51.

ISSN: 2013-2247

\section{Romance parallel constructions}

Some similar constructions are found in other Romance languages; especially French (16a), Italian (16b) and Catalan (16c) (cf. Di Tullio 2011: 185):

(16) a. C'est ce que (moi) j'essaie humblement de faire. ('That is what I humbly try to do').

b. Questo é ció che cerco di fare. ('That is what I try to do').

c. Això és el que jo humilment intento de fer. ('That is what I humbly try to do').

Evidence from these languages suggests that de (or $d i$ ) is better analysed as a complementizer. For instance, both in Italian and French, when the preposition is selected by the verb (meaning that it also precedes nominal arguments) it can be pronominalized by ne/en, while in cases like (16) it is pronominalized as a prepositionless object (cf. Skytte, Salvi \& Manzini 2001; Huot 1981).

Although these constructions in other Romance languages are certainly similar (absolutely identical in some cases), they cannot be seen as exact parallels: generally, de introduces declarative clauses in Italian (Ti prego di ascoltare 'Te ruego escuchar; I beg you listen') and French (Pauline a essayé de jouer au tennis 'Paulina ha intentado jugar al tenis; Paulina has tried to play tennis').

Moreover, some of the most frequent verbs that show deísmo in Spanish (perception verbs and manipulation verbs, for instance) do not take the preposition in Italian or in French, for example (Skytte, Salvi \& Manzini, 2001; Huot 1981; Vittorini 1942). In addition, the fact that this construction is found in the standard varieties of these languages probably accounts for the fact that there seems to be less variation in the presence or absence of the preposition. The fact that these constructions are not identical in all Romance languages does not mean that they are unrelated, but that they have developed differently (although likely from a common source). 


\section{Theoretical interpretations}

Several explanations have been offered in the literature for the presence of $d e$ in these and other related (such as dequeismo) constructions. It is important to bear in mind that this construction already existed in Old Spanish, that is to say, that the deísmo is not a modern dialectal innovation, but an inherited construction. However, this raises more questions, since both the disappearance of the preposition in Standard Spanish and its survival in other varieties have to be addressed.

Some authors, such as Gómez Torrego (1999), propose that both dequeísmo and deismo have an analogical explanation. According to this hypothesis, structures that require the presence of the preposition such as haber de, deber de, dejar de, tratar de, acabar de, parar de y cesar de, among others, would have determined the appearance of the preposition in similar contexts.

On the other hand, Di Tullio $(2011,2012)$ and Camus $(2013)$ both propose that the preposition de is a complementizer that introduces non-finite clauses. Although their proposals are not identical ( $\mathrm{Di}$ Tullio confers a semantic value to the complementizer that Camus thinks is absent in the Ciudad Real situation), they both make good points about why the preposition is not introducing a prepositional clause.

Nevertheless, as Camus has also shown, the complementizer hypothesis is problematic, as it does not account for the data of Andalusia and Extremadura. According to him, in Castilla-La Mancha every deísmo construction has a finite correlate, which would mean that it is an example of complementation. However, as we have shown and as he also acknowledges, the periphrasis type (number (6) in our classification) does not fit this description.

As it was noted above, prepositional infinitives have been increasing in Romance languages since early times (Schulte 2007). It seems that Standard Spanish eliminated some medieval solutions, assimilating infinitival clauses to noun phrases. In this system, adjunct infinitival clauses and infinitive clauses in oblique positions are headed by prepositions, while infinitive clauses in subject or direct object position reject them

- just as noun phrases do. Southern varieties, on the other hand, preserved the other 
Dialectologia. Special issue, $\mathbf{V}$ (2015), 29-51.

ISSN: 2013-2247

tendency that was already present in Medieval Spanish: introducing infinitives by prepositions, regardless its syntactic role. ${ }^{12}$

The hypothesis we would like to pursue here is related to this increase of prepositional infinitives. We propose that what we find in the Spanish varieties with deísmo represents the different stages of the spread of the preposition de as a particle that introduces infinitives, such as English ${ }^{13}$ to or Romanian $a$.

According to our proposal, the verb types 1 and 2, where the preposition have an original 'source' meaning and a verbal complex in which the bare noun may be interpreted as a syntactic antecedent of the infinitive (and the infinitive also as the source of the feeling described by the noun) would have been the original contexts (see Elvira 2011). At this stage the preposition would have had both semantic and syntactic value - at least originally - (which explains that we can find examples where the preposition precedes also noun phrases, such as Me da miedo del perro, Me da pena de mamá, No me importa de nadie (Díaz Montesinos 2012) - and Old Spanish Me plugo del vino, etc.). Syntactically, there are some constructions related to these that require the use of the preposition: Me da miedo de is related to Tengo miedo de, Es costumbre de to Tengo la costumbre de, etc. This also explains why the generalized preposition is a source preposition (de) and not a goal one (Eng. to, Rom. a).

At a second stage, the preposition would have been gramaticalised as a complementizer that introduces infinitive clauses, which happened in many Romance languages, as we have seen above. The fact that this development in Spanish happened in non Standard varieties may account for the fact that in Spanish deismo seems to appear with more verb types than in other Romance languages. It is likely

\footnotetext{
${ }^{12}$ However, we should not forget the fact that the construction is also present, although more rare, in Northern varieties. Are these residual cases of the medieval construction? If so, a deeper study would provide very interesting insight on how such a low-frequency construction preserved some productivity. Or, are they just newly created examples on the basis of a productive pattern of the language? As Elvira (2009a) says, regarding impersonal constructions with de prepositional phrases: "[...] no hay que descartar que la reaparición tardía de estas construcciones pueda deberse sencillamente a la permanente disponibilidad de este tipo de nociones de sensación y experiencia para distanciarse del patrón de expresión transitiva" ['We should not discard that the late reapparition of these constructions may be simply due to the permanent availability of the notions of emotion and experience to get away from the transitive pattern'] (Elvira 2009a: 143; cf. Díaz Montesinos 2012, our translation).

13 It seems that the most common source for infinitive particles are purposive constructions (Haspelmath 1989), as occurred in English and Romanian.
} 
that the Standard variety prevented the generalization of the preposition to other verb types in those languages (Italian, French, and Catalan). Moreover, the influence of similar constructions can also be detected in some manipulation verbs: dejar de 'stop'/ dejar de 'allow', hacer de 'prepare'/ hacer de 'cause, make'. Examples such as hacer de comer seem to have influenced those like hacer de correr, and we can actually see how it is gradually entering the Standard language: hacer de comer 'hacer comida/*hacer que coma' > hacer de reír 'hacer risa/hacer que ría' > hacer de correr 'hacer que corra'. ${ }^{14}$

The last stage corresponds to the periphrasis type (cf. 6), as its reduced frequency and geographical area also suggest. Here de does not introduce independent clauses (since they do not have a correlative que finite clause, cf. Camus 2013) but rather the finite verb in a verbal phrase. ${ }^{15}$ It seems likely that analogy has played a role in the development of this new type, as Gómez Torrego (1999) suggests. That is to say, other verbal periphrasis that require de before the infinitive, such as haber de, deber de, dejar de, tratar de, acabar de, parar de and cesar de, may have influenced the development of this last step. Other cases that allow for the appearance of de before an infinitive could have also played a role.

\section{Final conclusions}

In this paper, we have presented an overview of deismo in Peninsular Spanish and the many questions it raises. Thanks to the data from the COSER we have

\footnotetext{
${ }^{14}$ Camus' (2013) data in Ciudad Real are somewhat problematic for our account, since he only documents examples of this second stage in Ciudad Real, while he states that types 1 and 2 (in our account) are missing. However, it is possible that his method of collecting data (not specified in his paper) has played a role in this absence, since these are the most well-known examples and probably the most stigmatised as well, which means that speakers may deny they are using them when addressed directly. In the COSER data we have found several examples of these types (with V1s such as gustar, dar miedo, dar gusto, dar lástima, hacer falta and tener por costumbre) both in Albacete and in Cuenca, and also in Ciudad Real (for example COSER-1420, Tomelloso).

${ }^{15}$ Camus does not find this type in Ciudad Real and does not consider them cases of deísmo, since they do not fit in his conception of de as a complementizer, and proposes that they are just cases of analogy with other verbal periphrasis. If this is true, however, we would not expect that deísmo with modal V1s were documented only in a subset of the area that presents all the other cases of deísmo and precisely in the one that seems to use deísmo more frequently, as it actually happens.
} 
Dialectologia. Special issue, $\mathbf{V}(2015), 29-51$.

ISSN: 2013-2247

managed to describe both its geographical distribution and some of its characteristics, as well as the types of verbs that participate in this construction. Previous approaches to the phenomenon had not used systematic data coming from real corpora, probably causing their descriptions to be somehow inexact.

After a review of the state of the art, where a discussion on whether de is a preposition or a complementizer is taking place, we have proposed a (diachronic and diatopic) hypothesis according to which both answers would be partially correct. That is to say, originally de preserved its preposition features and meaning and it was later gramaticalised as a complementizer. In a later stage, it would have become an infinitive particle, such as English to. It is likely that these three stages are still alive in different subareas of the deismo area. This hypothesis predicts that different types of deísmo are to be found both in different areas and in different times. We would like to further pursue such a hypothesis in future work. In order to do so, a thorough diatopic and diachronic description of the phenomenon, on the basis of corpora data, would have to be provided, so as to show what types of deísmo are most common and where (both nowadays and in previous times, since we should not forget that the phenomenon existed already in Old Spanish). Only such a thorough description would allow us to determine whether deísmo is related to dequeísmo, which occurs in finite clauses, and whether the presence or the absence of the preposition triggers some difference of meaning.

\section{References}

ALEA = Atlas Lingüístico y Etnográfico de Andalucía, M. Alvar (dir.), Granada: Universidad de Granada/Madrid, CSIC, 6 vols.

ALECMAN = Atlas lingüístico ( $y$ etnográfico) de Castilla-La Mancha, P. García Mouton \& F. Moreno Fernández (dirs.), Alcalá de Henares: Universidad de Alcalá.

AlmeidA, M. (2009) “Priming y efectos mecánicos en la variación lingüística: el (de)queísmo en una comunidad canaria", Boletín de Filología, XLIV (1), 11-37.

ALPI = Atlas Lingüístico de la Península Ibérica, Madrid: CSIC. 
BEARDSLEY, W. A. (1921) Infinitive Constructions in Old Spanish, New York: Columbia University Press.

Camus Bergareche, B. (2013) "On Deísmo. Another Case of Variation in Spanish Complementation", Catalan Journal of Linguistics, 12, 13-39.

CASAS, A. (2004) "Exclamativas y expletividad. El que enfático", Revista de Filología Española, LXXXIV/2, 265-284.

COSER = Corpus Oral y Sonoro del Español Rural, I. Fernández-Ordóñez (dir.), Madrid: Universidad Autónoma de Madrid.

DEMONTE, V. (2003) "Microvariación sintáctica en español. Rasgos, categorías y virus", in P. Álvarez-Santullano, M. Rosas, M. Contreras \& P. Jiménez (eds.), Texto, Lingüística y Cultura, Osorno: Universidad de Los Lagos/Sociedad Chilena de Lingüística, 9-40.

DEMONTE, V. \& O. FERNÁNDEZ SORIANO (2001) “'Dequeísmo' in Spanish and the structure and features of COMP", in J. Herschensohn, E. Mallen \& K. Zagona (eds.), Features and Interfaces, Amsterdam-Philadelphia: John Benjamins, 50-70.

Demonte, V. \& O. Fernández SORIANo (2005) "Features in Comp and syntactic variation. The case of 'dequeísmo' in Spanish", Lingua, 115.8, 1063-1082.

DíAZ Montesinos, F. (2012) “¿Me gusta leer o me gusta de leer? Fundamentación gramatical e histórica de la variación preposicional en estructuras biactanciales estativas”, in J. A. Villena Ponsoda \& A. M. Ávila Muñoz (eds.), Estudios sobre el español de Málaga, Madrid: Sarriá, 353-382.

Di Tullio, A. (2011) "Infinitivos introducidos por de", Cuadernos de la ALFAL, 3, 176-187.

DI TUlLIO, A. (2012) “Oraciones completivas de infinitivo introducidas por de en el español moderno", in T. E. Jiménez Juliá et al. (coords.), Cum corde et in nova grammatica: estudios ofrecidos a Guillermo Rojo, Santiago de Compostela: Universidad de Santiago de Compostela, 265-276.

ELVIRA, J. (2009a) "El retroceso de la impersonalidad en español", Romanística sin complejos. Homenaje a Carmen Pensado, Berna: Peter Lang, 123-145.

ELVIRA, J. (2009b) “Construcciones y significado: Aspectos diacrónicos de la transitividad en español", Seminario Internacional Corrientes de estudio en semántica y pragmática históricas, 23-24 de noviembre de 2009, Madrid: Instituto Menéndez-Pidal. [http://www.uam.es/personal_pdi/filoyletras/javel/construc.pdf].

ELVIRA, J. (2011) "Constructions of uncontrolled state or event. The increase in productivity of a new argument structure in Old Spanish", Constructions and Frames, 3.2, Amsterdam: John Benjamins, 184-207. 
Dialectologia. Special issue, V (2015), 29-51.

ISSN: 2013-2247

Gómez TORREGO, L. (1999) "La variación en las subordinadas sustantivas. Dequeísmo y queísmo", in I. Bosque \& V. Demonte (dirs.), Gramática descriptiva de la lengua española, Madrid: Espasa Calpe, vol. 2, 2105-2148.

FernÁNDEZ-OrdóÑEZ, I. (2007) “Nuevas perspectivas en el estudio de la variación dialectal del español: El Corpus Oral y Sonoro del Español Rural (COSER)", in D. Trotter (ed.), Actes du XXIV Congrès de Linguistique et Philologie Romanes, Tübingen: Max Niemeyer, vol. 3, 2944.

HASPELMATH, M. (1989) "From purposive to infinitive -a universal path of grammaticalization", Folia Linguistica Historica, X (1-2), 287-310.

Hernanz, M. L. (1999) "El infinitivo", in I. Bosque/V. Demonte (eds.), Gramática descriptiva de la lengua española, Madrid: Espasa Calpe, vol. 2, 2197-2356.

HuOT, H. (1981) Constructions infinitives du français, Genève/Paris: Droz.

LLORENTE, A. (1980) “Consideraciones sobre el español actual”, Anuario de Letras, XVIII, 5-61.

Martínez díAz, E. \& M. R. Vila Pujol (2012) "La artificialidad prescriptiva y el uso de las perífrasis $<$ deber + infinitivo $>$ y $<$ deber + de + infinitivo $>$ en la Historia de la Lengua Española", Actas del VIII Congreso de Historia de la Lengua Española, Santiago de Compostela: Meubook, vol. I, 911-922.

MEYER-LÜBKE, W. (1890-1906) Grammaire des langues romanes, Paris/Leipzig: Welter, vol. III.

NGLE = Real Academia Española/Asociación de Academias de la Lengua Española. 2009. Nueva gramática de la lengua española, Madrid: Espasa.

PATo, E. (2014) “En llegando los datos, la intuición se matiza. El gerundio preposicional en la historia de la lengua española", RILCE, Revista de Filología Hispánica, 30/3, 833-860.

PAto, E. \& C. de Benito (2012) "Sobre el infinitivo con de en castellano meridional", Edisyn Workshop on Ibero-Romance Dialects: Clitics and Beyond, Getafe: Universidad Carlos III.

SCHULTE, K. (2007) Prepositionals Infinitives in Romance: A Usage-Based Approach to Syntactic Change, Bern: Peter Lang.

SkYtTe, G., G. Salvi \& M. R. MANzINI (2001) “Frasi subordinate all infinito", in L. Renzi \& G. Salvi (eds.), Grande grammatica italiana di consultazione, Bologna: II Mulino, vol. 2, 483-569.

VITTORINI, D. (1942) "Use of Prepositions before the Infinitive Mood in the Romance Languages", The Modern Language Journal, 26(6), 439-441.

ZAMORA VICENTE, A. (1970) Dialectología española, Madrid: Gredos. 